\title{
The Effect of Induced Hyperglucagonaemia on the Zucker Fatty Rat
}

\author{
H. A. Mahmood, P. J. Wood ${ }^{1}$, and V. Marks ${ }^{2}$ \\ Division of Clinical Biochemistry, Department of Biochemistry, University of Surrey, Guildford, England
}

Summary. The effect of chronic treatment with a long-acting glucagon preparation on liver glucagon and insulin receptors, adenylate cyclase and plasma lipids has been examined in Zucker fatty rats (fa/fa) and their lean littermates $(\mathrm{Fa} /-)$. Liver insulin and glucagon receptors were examined using radioreceptor assay techniques. Neither fatty nor lean rats showed any change in insulin receptors after glucagon treatment. Glucagon receptors of the fatty rats showed a $33 \%$ drop in the number of the glucagon receptors after glucagon treatment, whilst there was no such change in the lean group. Plasma membranes of the treated fatty rats and their controls bound only $50 \%$ as much insulin per $\mathrm{mg}$ of liver membrane protein as those of the treated lean rats and their controls. Glucagon treatment raised plasma NEFA in lean rats and reduced them in fatty ones. Plasma cholesterol levels were reduced in both groups of animals as were plasma triglycerides, though to a lesser degree in fatty than in lean animals. Glucagon treatment increased basal and stimulated adenylate cyclase activity in the lean rats and even more so in the fatty ones. The data lend no support to the concept that hypertriglyceridaemia in fatty Zucker rats is a consequence of abnormal glucagon responsiveness.

Key words: Long-acting glucagon, Zucker fatty and lean rats, adenylate cyclase, radioreceptor assay, Scatchard analysis.

Glucagon is well recognised to have lipolytic activity, both in vivo and in vitro in a wide range of species. The in vitro activity is readily demonstrated in tissues

1 Present address: Department of Chemical Pathology, Southampton General Hospital, Tremona Road, Southampton S09 4 $\mathrm{XY}$, UK

2 Reprints from Professor V. Marks derived from both mammals and birds. In vivo activity is, however, more difficult to demonstrate in mammals due to the concomitant stimulation, by glucagon, of insulin secretion, whose lipogenic action more than counterbalances the lipolytic effect of glucagon. Nevertheless, when its insulinotropic effect is abolished by prolonged fasting, glucagon can be shown to possess lipolytic activity in man [1] probably, as in other species through activation of adenylate cyclase activity and increased production of cyclic adenosine-3', 5'-monophosphate (cAMP).

Glucagon has a hypolipidaemic (hypolipoproteinaemic) action in man, dog, fowl and rat [2-5] and when administered to hyperlipaemic patients whether for a short time [6], or for longer periods [7], it produced a moderate to profound fall in plasma triglyceride and cholesterol levels. The hypolipidaemic effect has variously been attributed to reduction in hepatic triglyceride output [8] or to decreased apoprotein synthesis [9].

The Zucker fatty rat (fa/fa) suffers from a genetic type of obesity [10]. It is also hyperlipaemic, hyperinsulinaemic [11] and insulin resistant [12]. The hyperlipaemia in the species has been postulated as being due to glucagon resistance [13].

In order to try and further elucidate the mechanism of the hypolipaemic action of glucagon we have studied the effect of its long term administration in Zucker fatty rats $(\mathrm{fa} / \mathrm{fa})$ and their lean $(\mathrm{Fa} /-)$ littermates.

\section{Materials and Methods}

Ten week-old genetically fatty (fa/fa) male Zucker rats $[10]$ and their lean controls $(\mathrm{Fa} /-)$ were bred and supplied by the University of Surrey Animal Unit. Animals were fed a commercial pellet diet (Spratt Lab. Diet No. 1) ad libitum. The diet contains $4.5 \%$ fat, $21.5 \%$ protein and $42 \%$ carbohydrate. 
The animals were treated with long-acting glucagon (zinc protamine glucagon), a gift from Novo Industrie $\mathrm{A} / \mathrm{S}$, Copenhagen. A dose of $50 \mu \mathrm{g}$ of zinc protamine glucagon was administered by subcutaneous injection into the abdominal region to each rat twice a day at $10 \mathrm{a} . \mathrm{m}$. and $3 \mathrm{p}$. m. for a period of two weeks. The dose of glucagon was reduced to one injection a day for a third and final week because, by the end of the first two weeks of glucagon treatment, the animals had become lethargic and inactive. Reduction in the dosage of glucagon was associated with restoration of full activity. Controls were set up for each of the fatty and lean groups of experimental animals and treated exactly the same as the experimental animals, except that saline was injected subcutaneously instead of glucagon.

Twenty four hours after the last injection the animals were anaesthetised by intraperitoneal injection of Nembutal (Abbott Laboratories), $6 \mathrm{mg} / 100 \mathrm{~g}$ body weight (animals had access to food and water up to the time the experiment began). Blood was collected, by heart puncture, into a $10 \mathrm{ml}$ syringe containing Trasylol (Bayer, Germany) 2,000 KIU per $\mathrm{ml}$ of blood and added to a plastic pot containing $10 \mathrm{IU}$ heparin per $\mathrm{ml}$ of blood and centrifuged at $4^{\circ} \mathrm{C}$. Aliquots $(0.5 \mathrm{ml})$ of each plasma sample were pipetted into small fluoride-oxalate tubes for glucose determination. The remainder was stored at $-20^{\circ} \mathrm{C}$ until assayed.

Five grams of liver from each rat were collected and partially purified plasma membranes prepared according to a modification of the method of Ray [14]. The liver was homogenised in a hypotonic calcium chloride/sodium bicarbonate buffer, $\mathrm{pH} 7.5$, the homogenate was diluted $1: 100$ times $(\mathrm{w} / \mathrm{v})$ in the same buffer and separated by centrifugation at low speed. The intact liver plasma membranes fraction thus sedimented with the nuclear fraction was then diluted 50 times $(\mathrm{v} / \mathrm{v})$ with the same buffer and spun again. The plasma membranes were purified using two sucrose density gradients instead of the four used by Ray, i. e. $42 \mathrm{~g}$ and $48 \mathrm{~g}$ sucrose per $100 \mathrm{~g}$ water. A solution containing $0.25 \mathrm{~mol} / 1$ sucrose in $0.5 \mathrm{mmol} / 1$ tris- $\mathrm{HCl}$ buffer $(\mathrm{pH} 7.5)$ was layered on the mixture to protect the membranes from dehydration. The sucrose density gradient tubes were then spun at $25,000 \mathrm{rev} / \mathrm{min}$ for 2 hours. This modification gave a better yield of membranes, with higher basal and stimulated adenylate cyclase activity than the original method, without adverse effect on either insulin or glucagon binding. After washing three times with $30 \mathrm{mmol} / 1$ tris- $\mathrm{HCl}$ buffer, $\mathrm{pH} 7.4$, the membrane preparations were stored in small aliquots of 1-2 mg membrane protein and stored in liquid nitrogen until used.
Protein was determined by the method of Goodwin and Choi (15), $\mathrm{Mg}^{++}$-stimulated ATPase (EC 3.6.1.3) and 5 '-mononucleotidase (EC 3.1.3.5) by the method of Lesko et al. (16).

Adenylate cyclase (EC 4.6.1.1) was determined using a modification of the method of Bataille et al. [17]. The standard adenylate cyclase assay incubation mixture contained, in a total volume of $250 \mu \mathrm{l}$, the following concentrations of materials: $30 \mathrm{mmol} / 1$ Tris- $\mathrm{HCl}$ buffer, $\mathrm{pH} 7.5 ; 2.5 \mathrm{mmol} / 1$ theophylline, $1.5 \mathrm{mmol} / 1 \mathrm{ATP} ; 1 \mathrm{mmol} / 1 \mathrm{EDTA}, 5 \mathrm{mmol} / 1 \mathrm{mag}$ nesium sulphate, $1 \mathrm{mg} / \mathrm{ml}$ creatine kinase (EC 2.7.3.2), $20 \mathrm{mmol} / 1$ phosphocreatine, $0.12 \mathrm{mmol} / 1$ GTP and 40-60 $\mu \mathrm{g}$ membrane protein. Solutions of the reactants were made up in $10 \times$ the above concentrations. Equal volumes of the reactants were mixed and $200 \mu \mathrm{l}$ were pipetted into $7.5 \times 0.8 \mathrm{~cm}$ glass tubes. $25 \mu \mathrm{l}$ of either $100 \mu \mathrm{g} / \mathrm{ml}$ glucagon or $100 \mathrm{mmol} / \mathrm{l}$ sodium fluoride was added to the appropriate tube to give a final concentration of $10 \mu \mathrm{g} / \mathrm{ml}$ glucagon or $10 \mathrm{mmol} / 1 \mathrm{NaF}$ respectively.

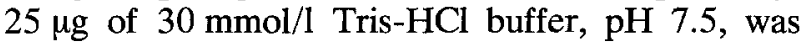
added to the basal level tubes to make up the final volume. The tubes were equilibrated for $10 \mathrm{~min}$ at $30^{\circ} \mathrm{C}$. The reaction was started by the addition of $25 \mu \mathrm{l}$ of membrane protein and allowed to proceed for $15 \mathrm{~min}$ at $30^{\circ} \mathrm{C}$. The reaction was terminated by immersing the tubes in a boiling water bath for $2 \mathrm{~min}$. cAMP produced was measured by a saturation assay method [18].

The glucagon radioreceptor assay was carried out using a modification of the method described by Holst [19]. Monoiodinated monocomponent ${ }^{125} \mathrm{I}-$ labelled glucagon was prepared according to the method of Jørgensen and Larssen [20] and had a specific activity of $250-300 \mu \mathrm{Ci} / \mu \mathrm{g}$. Incubations were carried out in plastic LP3 tubes of $2.7 \mathrm{ml}$ capacity.

Each tube contained a total of $400 \mu$ l of the following: $100 \mu$ l Krebs-Ringer phosphate (KRP) buffer, $\mathrm{pH} 7.4$, containing $1 \%$ gelatin; $30 \mathrm{pg}{ }^{125} \mathrm{I}$-glucagon in $100 \mu \mathrm{l}$ buffer $(10,000 \mathrm{cpm}), 100 \mu \mathrm{l}$ glucagon standards (as shown in Figures) and $100 \mu$ plasma membrane suspension containing $100 \mu \mathrm{g}$ protein. After mixing and incubating for $30 \mathrm{~min}$ at $30^{\circ} \mathrm{C}$, the tubes were centrifuged at $2,000 \mathrm{xg}$ for $20 \mathrm{~min}$ at $10^{\circ} \mathrm{C}$. The supernatant was discarded and the pellet washed twice with the KRP buffer. Radioactivity was counted using an LKB-Wallac 8000 gamma counter. Non-specific binding (NSB) tubes, representing the percentage of ${ }^{125} \mathrm{I}$-radioactivity bound to membrane pellets in the presence of high concentration of unlabelled glucagon $(50 \mu \mathrm{g})$ were included for each test. The NSB values obtained were subtracted from each of the test results. Tests were carried out in duplicate. 
Table 1. Average weights of the Zucker rats before and after glucagon treatment with their controls: plasma glucose, insulin and glucagon levels

\begin{tabular}{|c|c|c|c|c|c|c|}
\hline & \multicolumn{3}{|c|}{ Average weight $-\mathrm{g}$} & \multirow{2}{*}{$\begin{array}{l}\text { Plasma glucose } \\
\mathrm{mmol} / 1\end{array}$} & \multirow{2}{*}{$\begin{array}{l}\text { Plasma insulin } \\
\mathrm{mU} / 1\end{array}$} & \multirow{2}{*}{$\begin{array}{l}\text { Plasma glucagon } \\
\text { ng/1 }\end{array}$} \\
\hline & Before tr & atment & After treatment & & & \\
\hline \multirow[t]{2}{*}{ Zucker lean } & Control & $337 \pm 5.6$ & $372 \pm 16$ & $\mathrm{~V}^{7.9 \pm 0.5}$ & $\mathrm{~V}^{47.5 \pm 9}$ & $\begin{array}{l}<50 \\
\mathrm{~V}\end{array}$ \\
\hline & Treated & $338 \pm 10$ & $376 \pm 14$ & $8.88 \pm 0.9^{\mathrm{a}}$ & $152.5 \pm 31^{\mathrm{b}}$ & $125 \pm 8$ \\
\hline \multirow[t]{2}{*}{ Zucker fatty } & Control & $470 \pm 9.5$ & $527 \pm 7$ & $\begin{array}{l}11.4 \pm 1.3 \\
V\end{array}$ & $\begin{array}{l}806 \pm 98 \\
V\end{array}$ & $\begin{array}{l}80 \pm 34 \\
V\end{array}$ \\
\hline & Treated & $469 \pm 3.5$ & $517 \pm 6$ & $7.66 \pm 0.3^{b}$ & $750 \pm 139^{\mathrm{a}}$ & $505 \pm 106^{b}$ \\
\hline
\end{tabular}

$\mathrm{a}=\mathrm{p}$ not significant

$\mathrm{b}=\mathrm{p}<0.01$

Iodinated bovine monocomponent insulin was prepared by a lactoperoxidase method [21] and had a specific activity of $200-300 \mu \mathrm{Ci} / \mu \mathrm{g}$. The insulin radioreceptor assay was carried out as described for glucagon, substituting insulin for glucagon and calcium-free KRP buffer containing $4 \%$ glucose and $1 \%$ gelatine for the buffer used in the glucagon radioreceptor assay. Calcium has been shown [22] to interfere with maximum insulin binding to liver plasma membranes and glucose to enhance it.

Carrier-free $\mathrm{Na}^{125} \mathrm{I}$ and cyclic $\left[8{ }^{3} \mathrm{H}\right]$ AMP, specific activity $28 \mathrm{Ci} / \mathrm{mmol}$ were supplied by the Radiochemical Centre, Amersham. Crystalline porcine glucagon and crystalline bovine insulin (glucagon free) were kind gifts of Eli Lilly and Co., USA. 5' adenosine monophosphate (AMP), adenosine triphosphate (ATP) and guanine triphosphate (GTP) and other chemicals of Analar grade, were supplied by BDH Ltd., Poole, England. Creatine kinase and phosphocreatine were bought from Boehringer, Mannheim, Germany.

Insulin and glucagon degradation and inactivation by the liver plasma membranes during $30 \mathrm{~min}$ incubation at $30^{\circ} \mathrm{C}$ was determined by the loss of bindability of labelled hormones preincubated with membranes to fresh membranes as described by Freychet et al. [23].

Plasma insulin and glucagon were determined by radioimmunoassay using human insulin and porcine glucagon as standards. The glucagon antiserum used had a low cross-reactivity with gut extracts.

Plasma cholesterol was measured colorimetrically using the Liebermann-Burchard reaction (Boehringer Mannheim kit cat. no. 15949) with a coefficient of variation (CV) of $6 \%$. Plasma non-esterified fatty acids (NEFA) were determined after conversion to chloroform-soluble copper salts; the copper in the organic layer was subsequently measured colorimetrically (Boehringer-Mannheim kit cat. no. 126055) with a CV of $6 \%$. Plasma triglycerides were meas- ured using an enzymatic assay after saponification with ethanolic-potassium hydroxide (BoehringerMannheim kit cat. no. 125032) with a CV of 5\%. Plasma glucose was measured using a glucose method kit (Boehringer-Mannheim cat. no. 15755) with a $\mathrm{CV}$ of $3.3 \%$.

Each group of glucagon treated and their controls contained four animals. The results are expressed as the mean \pm SEM. Statistical analyses were carried out using the Student's t-test, to compare the results of the treated lean rats versus their controls and the treated fatty rats versus their controls.

\section{Results}

Long-term glucagon treatment had no effect on the rate of weight gain by either the lean or fatty experimental animals compared with their controls (Table 1).

Plasma glucose levels did not differ significantly in the treated and control lean animals. In the fatty rats there was a significant lowering $(p<0.01)$ of plasma glucose as a result of chronic glucagon treatment.

Plasma insulin levels were markedly elevated in fatty rats as compared with their lean controls. Plasma glucagon levels were also elevated but to a lesser degree. An insulinotropic effect of glucagon was demonstrated in the lean rats by a three fold increase in plasma insulin concentration after glucagon treatment, compared with the saline treated controls. The glucagon treated fatty rats did not show a significant increase in plasma insulin concentration compared with their controls in whom plasma insulin levels were already very high. It has been shown [30] that sodium pentobarbital slighly inhibits insulin released from pancreatic islets of obese mice in vitro when incubated in a medium containing physiological levels of glucose and calcium. Consequently, the 
Table 2. Plasma NEFA, cholesterol and triglycerides of the Zucker lean and fatty rats and the change in their levels expressed as percentages after glucagon treatment and their controls

\begin{tabular}{|c|c|c|c|c|c|c|c|}
\hline & & $\begin{array}{l}\mathrm{NEFA} \\
\mathrm{mmol} / 1\end{array}$ & $\%$ Change & $\begin{array}{l}\text { Cholesterol } \\
\mathrm{mmol} / \mathrm{l}\end{array}$ & $\%$ Reduction & $\begin{array}{l}\text { Triglycerides } \\
\mathrm{mmol} / \mathrm{l}\end{array}$ & $\%$ Reduction \\
\hline Zucker lean & $\begin{array}{l}\text { Control } \\
\text { Treated }\end{array}$ & $\begin{array}{l}0.39 \pm 0.04 \\
V \\
0.55 \pm 0.02^{b}\end{array}$ & $\uparrow 41$ & $\begin{array}{l}1.67 \pm 0.08 \\
V \\
1.30 \pm 0.09^{\mathrm{a}}\end{array}$ & 22 & $\begin{array}{l}1.10 \pm 0.07 \\
V \\
0.64 \pm 0.05^{\mathrm{c}}\end{array}$ & 42.4 \\
\hline Zucker fatty & $\begin{array}{l}\text { Control } \\
\text { Treated }\end{array}$ & $\begin{array}{l}0.52 \pm 0.01 \\
\mathrm{~V} \\
0.48 \pm 0.03^{\mathrm{a}}\end{array}$ & $\downarrow 7.6$ & $\begin{array}{l}4.68 \pm 0.2 \\
V \\
3.48 \pm 0.3^{b}\end{array}$ & 25.6 & $\begin{array}{l}4.0 \pm 0.4 \\
V \\
2.9 \pm 0.3^{d}\end{array}$ & 27.2 \\
\hline
\end{tabular}

$\mathrm{a}=\mathrm{p}$ not significant, $\mathrm{b}=\mathrm{p}<0.01,{ }^{\mathrm{c}}=\mathrm{p}<0.001, \mathrm{~d}=\mathrm{p}<0.02$

Table 3. Plasma membrane bound enzymes of the glucagon treated Zucker lean and fatty rats and their controls

\begin{tabular}{|c|c|c|c|}
\hline & & $\begin{array}{l}\text { 5'-Mono- } \\
\text { nucleotidase } \\
\text { umol phosphate } \\
\text { released/ } \\
30 \mathrm{~min} / \mathrm{mg} \\
\text { membrane pro- } \\
\text { tein }\end{array}$ & $\begin{array}{l}\mathrm{Mg}^{++}-\mathrm{Stimu}- \\
\text { lated ATPase } \\
\mu \text { mol phosphate } \\
\text { released/ } \\
30 \mathrm{~min} / \mathrm{mg} \\
\text { membrane pro- } \\
\text { tein }\end{array}$ \\
\hline Zucker lean & $\begin{array}{l}\text { Control } \\
\text { Treated }\end{array}$ & $\begin{array}{l}18 \pm 2.5 \\
23.5 \pm 4.5^{\mathrm{a}}\end{array}$ & $\begin{array}{c}9.7 \pm 1.2 \\
10.8 \pm 1.6^{\mathrm{a}}\end{array}$ \\
\hline Zucker fatty & $\begin{array}{l}\text { Control } \\
\text { Treated }\end{array}$ & $\begin{array}{l}12.5 \pm 2.0 \\
15.3 \pm 2.2^{\mathrm{a}}\end{array}$ & $\begin{array}{c}8.8 \pm 1.0 \\
10.2 \pm 1.4^{\mathrm{a}}\end{array}$ \\
\hline
\end{tabular}

${ }^{\mathrm{a}} \mathrm{p}=$ not significant

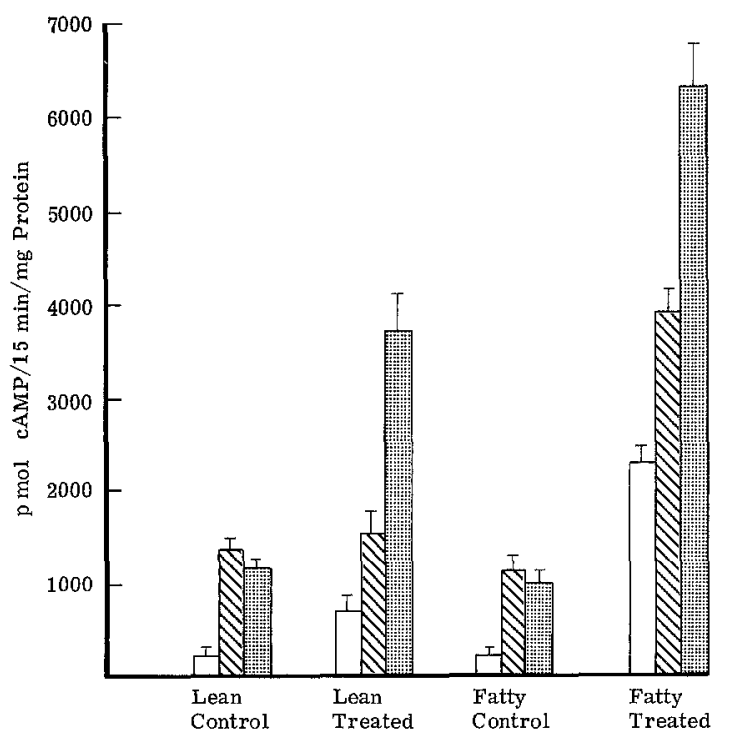

Fig. 1. Adenylate cyclase levels of the Zucker lean and fatty rats after glucagon treatment and their controls, basal ( $\square),+$ $10 \mathrm{mmol} / 1 \mathrm{NaF}(\mathbb{N})$ and $+10 \mu \mathrm{g} / \mathrm{ml}$ glucagon (国) stimulated levels absolute values shown in Table 1 and elsewhere may be an underestimate of the concentration in unanaesthetised animals. Nevertheless, assuming that the anaesthesia had the same effect on both the lean and the fatty rats, the insulin levels reported in this study are suitable for comparative purposes.

Mean plasma glucagon levels were below the lower limit of accurate measurement in the lean controls but were measurable in the fatty controls. At the conclusion of the experiment plasma glucagon levels were higher in the glucagon treated animals than in the controls. This was especially marked in the fatty rats in which terminal plasma glucagon levels were more than six times those of their untreated controls and over three times as high as in the glucagon treated lean rats.

Chronic administration of glucagon produced significant reduction in plasma triglycerides and cholesterol levels (Table 2) in both the lean and fatty animals. Treated lean rats showed a $42.4 \%$ reduction in plasma triglycerides compared with their controls; treated fatty rats, on the other hand, showed only a $27.2 \%$ reduction despite much higher levels initially. Glucagon treatment reduced plasma cholesterol levels more or less equally in the lean and fatty rats (22 and $25.6 \%$ respectively). Glucagon treatment increased plasma NEFA levels by $41 \%$ in the lean rats and reduced them by $7.6 \%$ in the fatty ones.

Values obtained for the plasma membrane marker enzymes, 5' mononucleotidase and $\mathrm{Mg}^{++}$ stimulated ATPase are shown in Table 3. Both enzymes demonstrated a slight, but statistically nonsignificant, increase in activity after glucagon treatment in both lean and fatty rats.

Membrane-bound adenylate cyclase activities after treatment are shown in Figure 1. The control lean and fatty rats did not differ significantly from each other (statistical values not shown). Glucagon treatment produced a significant increase in basal and stimulated levels, in both groups. The increase 
was greater in the fatty animals both in relative and absolute terms when compared to their own untreated controls and the treated lean animals.

In the stimulated state, however, the increment in adenylate cyclase activity produced by addition of glucagon in vitro though larger in absolute terms in the treated fatty rats was nonetheless smaller than in treated lean animals.

Specific binding of ${ }^{125} \mathrm{I}$-glucagon to liver plasma membranes prepared from lean and fatty Zucker rats and their controls and its displacement by unlabelled glucagon is shown in Figure 2. There were no differences in glucagon binding characterisation between the glucagon treated and untreated lean animals or the untreated fatty animals. Because of overlapping of the experimental values one displacement plot sufficed to represent the three groups of animals (control and treated lean and control fatty). There was, however, a marked and significant drop in glucagon binding by liver cell membranes prepared from glucagon treated fatty rats compared with their untreated controls.

Scatchard analysis [25] was carried out on the glucagon radioreceptor assay data shown in Figure 2 and represented diagramatically in Figure 3. The affinity and kinetic constants derived from the two plots are shown in Table 4. In both plots there appear to be two types of glucagon receptors; site 1 receptors having high affinity and low capacity; and site 2 receptors a low affinity and high capacity. There was a significant decrease in the binding capacity of both sites in membrane prepared from treated fatty rats compared with their untreated controls, the values being nearly halved by glucagon treatment. The reduction in capacity was accompanied by an increase in the affinity constant of site 2 in the fatty treated animals compared with their controls without significant change in site 1.
Specific binding of ${ }^{125} \mathrm{I}$-insulin to liver plasma membranes from lean and fatty rats and their controls and its displacement by unlabelled insulin is shown in Figure 4. Glucagon treatment did not alter insulin binding to liver receptors in either the treated lean and fatty animals as compared with their controls. However, maximum ${ }^{125} \mathrm{I}$-insulin binding by liver cell membranes from both control and treated fatty rats was only $50 \%$ of that obtained with the

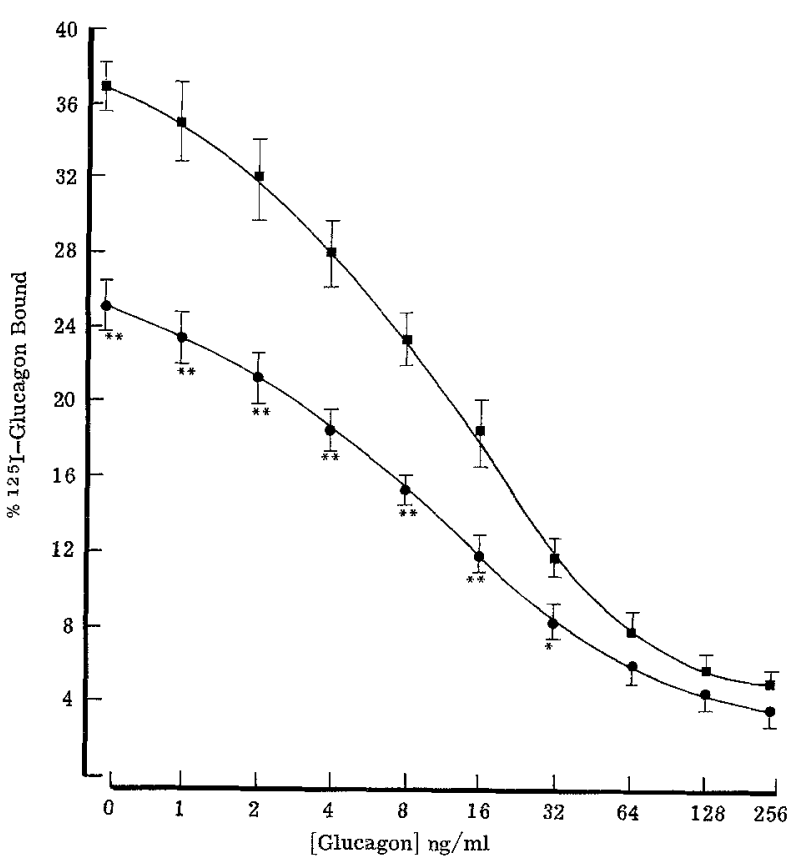

Fig. 2. Specific binding of ${ }^{125} \mathrm{I}$-glucagon $(75 \mathrm{pg} / \mathrm{ml})$ to partially purified liver plasma membranes from lean and fatty Zucker rats after glucagon treatment and their controls, and displacement by unlabelled glucagon. NSB for the treated lean and controls was $2.2 \%$ and for treated fatty and controls $2.6 \%$, which were subtracted from all results shown. (口) Lean treated and controls and fatty controls. (๑) "Fatty"-treated

Table 4. Apparent affinity constants and binding capacities of the Zucker lean and fatty rats after glucagon treatment and their controls. Site 1 is the low capacity high affinity site; site 2 is the high capacity low affinity site. The contribution of the low affinity binding site was subtracted from the results of the high affinity binding site as described by Olefsky et al. (24). Results were calculated from Figure 4 and Figure 5 for glucagon and insulin Scatchard analyses respectively

\begin{tabular}{|c|c|c|c|c|c|}
\hline & \multirow{2}{*}{ Hormone } & \multicolumn{2}{|c|}{$\begin{array}{l}\text { Maximum binding capacity } \\
\mathrm{pmol} / \mathrm{mg} \text { membrane protein }\end{array}$} & \multicolumn{2}{|c|}{$\begin{array}{l}\text { Apparent affinity constant } \\
\mathrm{L} / \mathrm{M}^{-1}\end{array}$} \\
\hline & & Site 1 & Site 2 & Site 1 & Site 2 \\
\hline $\begin{array}{l}\text { Zucker lean } \\
\text { treated and control }\end{array}$ & Insulin & 4.4 & 34.7 & $1.7 \times 10^{8}$ & $1.25 \times 10^{7}$ \\
\hline $\begin{array}{l}\text { Zucker fatty } \\
\text { treated and control }\end{array}$ & Insulin & 1.2 & 10.4 & $2.7 \times 10^{8}$ & $1.6 \times 10^{7}$ \\
\hline $\begin{array}{l}\text { Zucker lean treated and } \\
\text { control \& Z. fatty control }\end{array}$ & Glucagon & 11.0 & 72.9 & $4.4 \times 10^{8}$ & $1.7 \times 10^{7}$ \\
\hline Zucker fatty treated & Glucagon & 5.5 & 37.3 & $4.7 \times 10^{8}$ & $3.3 \times 10^{7}$ \\
\hline
\end{tabular}




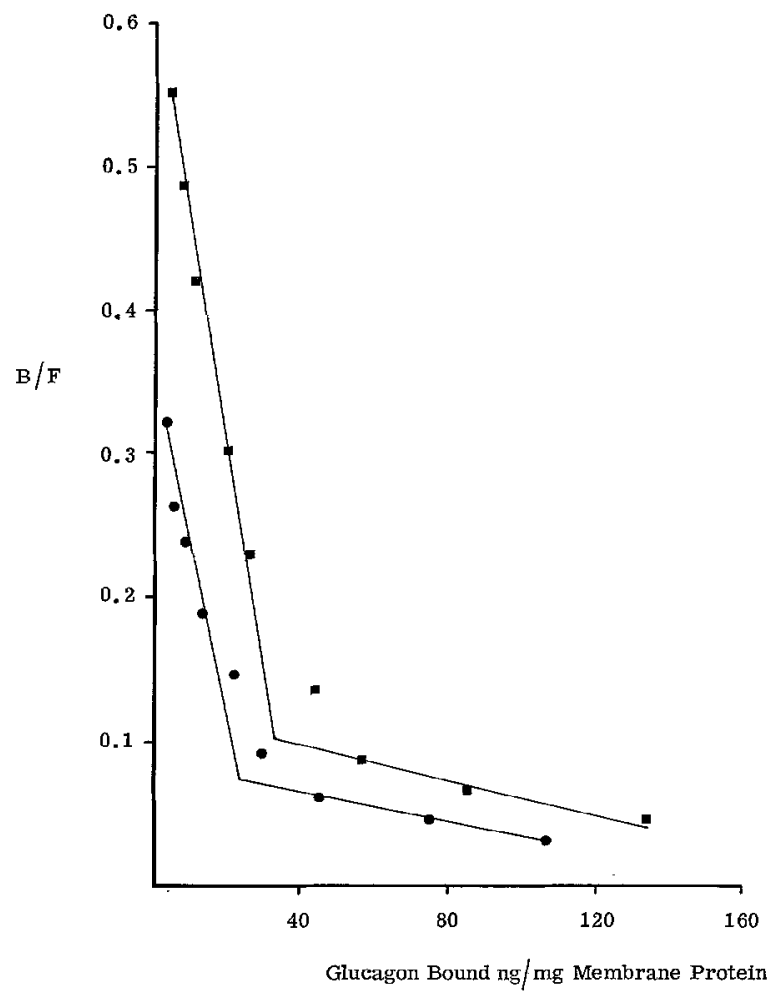

Fig. 3. Scatchard plot of the data in Fig. 2. The ratio of the bound to free glucagon is on the vertical axis and bound glucagon is on the horizontal axis. The association constant of the high affinity site is obtained from the slope of the straight line at low glucagon concentrations after correction for the contribution of the low affinity site at higher glucagon concentrations. The association constant of the low affinity site is obtained from the slope of the straight line at higher glucagon concentrations. The maximum binding capacities were calculated from the intercepts of these two

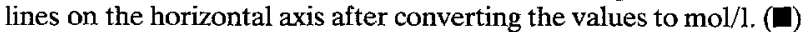
represents values from treated lean rats and their controls and fatty rats controls; $(\boldsymbol{\bullet})$ represent treated fatty rats

membranes prepared from livers of either control or glucagon treated lean rats.

Scatchard analysis of the insulin displacement studies are shown in Figure 5 and the calculated affinity and kinetic constants are shown in Table 4. Due to the overlapping of the results from the treated and control lean groups and the treated and control fatty groups, one Scatchard plot sufficed to describe the radioreceptor assay data obtained from the glucagon treated lean rats and their controls and another Scatchard plot to describe the data obtained from the glucagon treated fatty rats and their controls. For the sake of convenience two types of insulin receptors for each group of animals were extrapolated from the Scatchard plots, a high affinity low capacity (site 1) and a low affinity high capacity (site 2 ). The calculated data shown in Table 4 reveal a marked reduction in the maximum ${ }^{125}$ I-insulin binding capacity of liver plasma membranes obtained from the fatty rats compared with membranes from lean rats. This

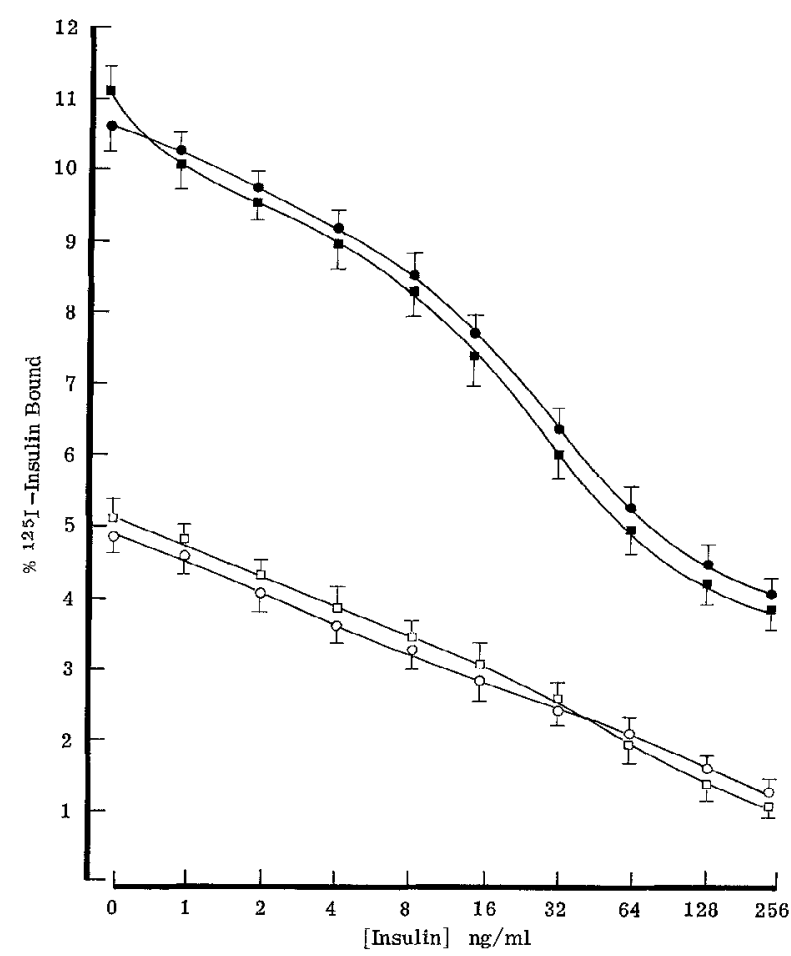

Fig. 4. Specific binding of ${ }^{125} \mathrm{I}$-insulin $(75 \mathrm{gg} / \mathrm{ml})$ to partially purified liver plasma membranes from lean and fatty Zucker rats after glucagon treatment and their controls, and displacement by unlabelled insulin. NSB for the treated lean and controls was $5.6 \%$ and for treated fatty and controls $4.9 \%$, which were subtracted from their respective results shown. ( $\square$ ) Treated lean, (๑) lean controls, (O) treated fatty and $(\square)$ fatty controls

reduction in binding capacity affects both sites and is probably compensated for by an increased binding affinity at both sites, particularly site 1 .

Table 5 shows insulin and glucagon degradation by the liver plasma membranes of the lean and fatty Zucker rats. These results indicate that degradation of both hormones is higher in the lean rats than from their fatty counterparts.

None of the glucagon-treated animals developed ${ }^{125}$ I-glucagon binding glucagon antibodies during the course of these experiments.

\section{Discussion}

The present study indicates that in the Zucker fatty rats, as in most other conditions associated with hyperinsulinaemia, there is impairment of insulin receptor interaction. This impairment on the surfaces of the liver cell membranes appears to consist mainly of a decrease in the number of insulin receptors. The 


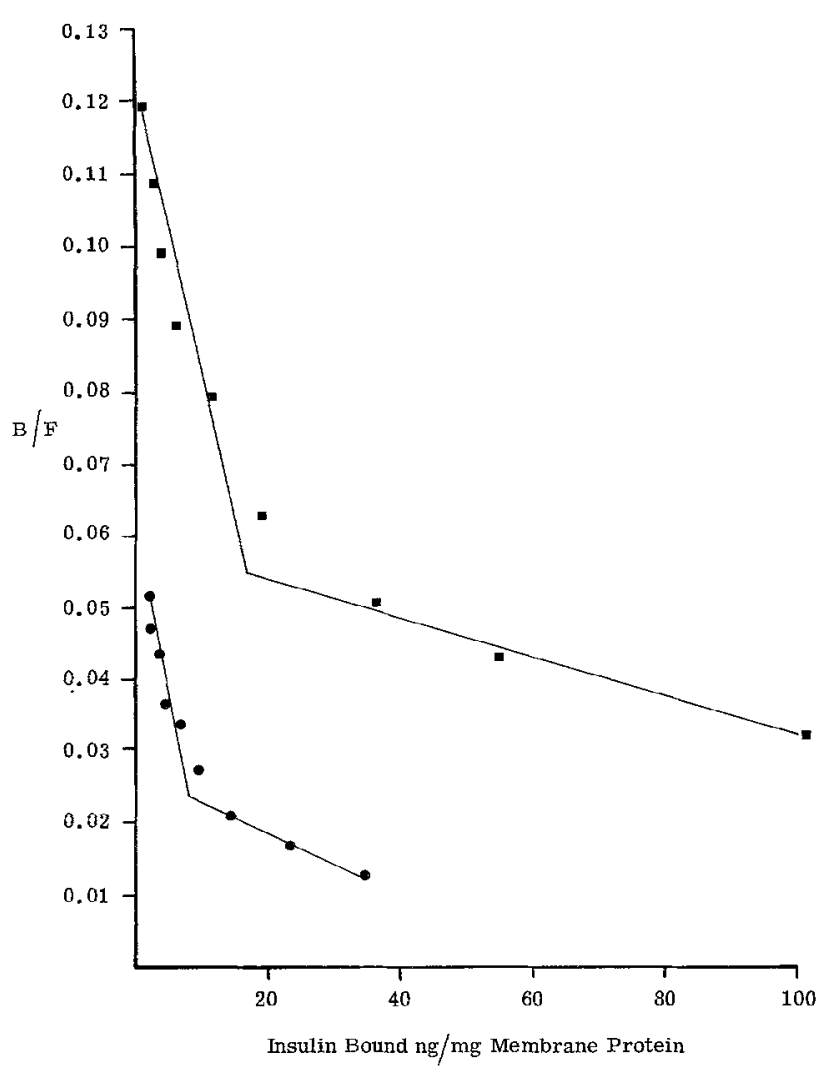

Fig. 5. Scatchard plot of the data in Fig. 4. Results were calculated as shown in the legend to Fig. 4. (D) represents values from treated lean and control rats; $(\bullet)$ represents values from treated fatty and control rats

Table 5. Insulin and glucagon degradation by the liver plasma membranes of lean and fatty Zucker rats. Degradation was determined by the loss of bindability expressed as percentage to fresh membranes after preincubation with liver plasma membranes $(0.33 \mathrm{mg} / \mathrm{ml})$ for $30 \mathrm{~min}$ at $30^{\circ} \mathrm{C}$. Hormones concentration was $0.75 \mathrm{ng} / \mathrm{ml}$

\begin{tabular}{lll}
\hline & Insulin & Glucagon \\
\hline Zucker lean & $43 \%$ & $37 \%$ \\
Zucker fatty & $35 \%$ & $20 \%$ \\
\hline
\end{tabular}

possibility that the reduced insulin binding observed with liver membranes from fatty $(\mathrm{fa} / \mathrm{fa}$ ) rats was not due to increased insulin degradation is shown by the results in Table 5. Our findings in the fatty rats do not agree with a previous report [26] that the binding of insulin to isolated hepatocytes was the same in cells obtained from fed homozygous fatty Zucker rats as those from their lean sibs. However, the same report showed that the specific binding of insulin was lower in the fasted obese than in the fasted lean rats. This discrepancy may be due to the use of whole liver cells as compared with isolated liver plasma membranes used for this study. Our findings throw no light on the problem as to whether the reduction in insulin binding sites is genetically determined or, as seems more likely, merely an adaptation to hyperinsulinaemia.

The decrease in the number of insulin receptors, relative to their respective lean controls, is much smaller in fatty (fa/fa) rats than is reported [27] for obese (ob/ob) mice which also exhibit marked hyperglycaemia. Liver cell membranes isolated from the obese mouse bound, at physiological concentrations of insulin, only $20-25 \%$ of the amount bound by membranes obtained from lean mice [27]. Greater reduction in the number of insulin receptors in the obese mouse may contribute to the greater hyperglycaemia and lower glucose tolerance found in this species compared with the Zucker fatty rat in which both are very mild or absent.

Liver cell plasma membrane glucagon receptors showed no difference in their binding capacity or association constants in fatty and lean rats from the Zucker strain. Glucagon resistance, postulated to account for the gross hyperlipidaemia observed in these animals [13], cannot, therefore, even if established, be explained on the basis of a reduction in the number and avidity of hepatocyte glucagon receptors.

The interpretation of Scatchard analysis where curvilinear plots are obtained depend upon certain assumptions. One of these is that site 1 and site 2 receptors act independently of each other. The data obtained here could be interpreted, according to this viewpoint, as being due to the presence of multiple classes of binding sites with different but fixed affinities. However, it has been shown [28] that curvilinear plots can also be explained by the existence of site-site interactions of the type defined as "negative cooperativity". Such site-site interactions have been postulated for insulin $[28,29]$. If this alternative explanation is correct values derived from Scatchard analysis of the data from lean and fatty rats may be useful for comparative purposes, but devoid of any physiochemical meaning.

Of interest is the difference in hypolipidacmic and hyperglycaemic potency of glucagon in fatty and lean Zucker rats. Although greater in fatty than in lean rats when expressed in terms of absolute reduction in plasma triglyceride levels, the situation is reversed when the data are expressed in terms of percentage reduction from pretreatment values. Plasma glucose levels were lower in glucagon treated than untreated fatty rats, despite the fact that plasma glucagon was increased and plasma insulin remained unchanged.

Prolonged exposure of Zucker rats to exogenous glucagon led to a marked rise in total adenylate cyclase activity through which the hormone is believed to exert its metabolic effect. The effect, both upon basal adenylate cyclase levels and its activity after 
stimulation in vitro was much greater in the fatty rats than the lean ones.

The differences in hypolipidaemic potency of glucagon in glucagon treated Zucker rats and their lean controls could possibly be explained by the fact that glucagon treated fatty rats show a fall in the number of glucagon receptors as a "down-regulation" response to high plasma levels of exogenous glucagon similar to that observed with insulin. Alternatively, the decreased lipolytic activity, as well as the lowering of plasma glucose shown by the glucagon treated fatty rats could be explained on the basis of the gross hyperinsulinaemia present in the fatty rats more than counterbalancing the effect of the induced hyperglucagonaemia. However, this explanation is made less likely if the reduction in the number of insulin receptors shown in Figure 4 is taken into account as probably indicative of increased insulin resistance.

In the present study the liver was studied as the probable main site of glucagon and insulin action. However, it is worth bearing in mind that other pools of triglyceride and glucose exist in the animal body where the two hormones might exert their effects. They could possibly differ in Zucker fatty and lean rats which may put different explanation in the above discussed discrepancies.

Acknowledgements. Our thanks and gratitude to Mr. Y. Y. AlTamer for helping with the preparation of the hormone labels and plasma glucagon determinations, and to Miss Wendy Green, Biochemistry Department, St. Luke's Hospital, Guildford, for the plasma insulin determinations.

\section{References}

1. Caren, R., Carbo, L.: Glucagon and cholesterol metabolism. Metabolism 9, 938-945 (1960)

2. Salter, J.H.: Metabolic effects of glucagon in the Wistar rat. Am. J. Clin. Nutr. 8, 535-539 (1960)

3. Paloyan, E., Harper, P. V., Jr.: Glucagon as a regulating factor in plasma lipids. Metabolism 10, 315-323 (1961)

4. Amatuzio, D.S., Grande, F., Wada, S.: Effect of glucagon on the serum lipids in essential hyperlysemia and in hypercholesterolaemia. Metabolism 11, 1240-1249 (1962)

5. DeOya, M., Prigge, W. F., Swenson, D. E., Grande, F.: Role of glucagon on fatty liver production birds. Am. J. Physiol. 221, 25-30 (1971)

6. Elkeles, R.S., Hambley, J.: Glucagon resistance as a cause of hypertriglyceridaemia. Lancet 1976 II, 18-20

7. Aubrey, F., Marcel, Y. L., Davignon, J.: Effects of glucagon on plasma lipids in different types of primary hyperlipoproteinaemia. Metabolism 23, 225-238 (1974)

8. Heimberg, M., Weinstein, I., Kohout, M.: The effects of glucagon, dibutyryl cyclic adenosine 3', 5' monophosphate and concentration of free fatty acid on hepatic lipid metabolism. J. Biol. Chem. 249, 5131-5139 (1969)

9. Eaton, R. P.: Hypolipemic action of glucagon in experimental endogenous lipemia in the rat. J. Lipid Res. 14, 312-318 (1973)

10. Zucker, L. M., Zucker, T. F.: Fatty, a new mutation in the rat. J. Hered. 52, 275-278 (1961)

11. Zucker, L.M., Antoniades, H.N.: Insulin and obesity in the genetically obese rat "fatty". Endocrinology 90, 1320-1330 (1972)
12. Stern, J., Johnson, P. R., Grecnwood, M. R. C., Zucker, L. M., Hirsch, J.: Insulin resistance and pancreatic insulin rclease in the genetically obese Zucker rat. Proc. Soc. Exp. Biol. Med. 139, 66-69 (1972)

13. Eaton, R.P., Schade, D. S., Conway, M.: Decreased glucagon activity: a mechanism for genetic and acquired hyperlipemia. Lancet 1974 II, 1545-1547

14. Ray, T.K.: A modified method for the isolation of the plasma membrane from rat liver. Biochim. Biophys. Acta 196, 1-9 (1970)

15. Goodwin, J. F., Siu-Ying Choi: Quantification of protein solutions with trinitrobenzene sulphonic acid. Clin. Chem. 16, 223-224 (1972)

16. Lesko, L., Donlon, M., Marinetti, G. V., Hare, J. D.: A rapid method for the isolation of rat liver plasma membrancs using an aqueous two-phase polymer system. Biochim. Biophys. Acta 311, 173-179 (1973)

17. Bataille, D. P., Freychet, P., Kitabgi, P. E., Rosslin, G. E.: Gut glucagon: a common receptor site with pancreatic glucagon in liver cell plasma membranes. FEBS Letts 30, 215-218 (1973)

18. Brown, B. L., Albano, J. D.M., Ekins, R. P., Sgherazi, A.M., Tampion, W.: A simple and sensitive saturation assay method for the measurement of adenosine 3', 5'-cyclic monophosphate. Biochem. J. 121, 561-562 (1971)

19. Holst, J. J.: A radioreceptor assay for glucagon: binding of enteroglucagon to liver plasma membranes. Diabetologia 11 211-219 (1975)

20. Jørgensen, K. H., Larsson, U. D.: Purification of ${ }^{125} \mathrm{I}$-glucagon by anion exchange chromatography. Horm. Metab. Res. 4, 223-224 (1972)

21. Suzuki, K., Ohsawa, N., Kosaka, K.: Radioreceptor assay for insulin. J. Clin. Endocrinol. Metab. 42, 339-402 (1976)

22. Robinson, A.R., Jr., Boshell, B.R., Reddy, W.J.: Insulin binding to plasma membranes. Biochim. Biophys. Acta 290, 84-91 (1972)

23. Freychet, P., Kahn, R., Roth, J., Neville, D. M., Jr.: Insulin interaction with liver plasma membranes: independence of binding of the hormone and its degradation. J. Biol. Chem. 247, 3953-3961 (1972)

24. Olefsky, J. M., Jen, P., Reaven, G. M.: Insulin binding to isolated human adipocytes. Diabetes 23, 565-571 (1974)

25. Scatchard, G.: The attraction of proteins for small molecules and ions. N. Y. Acad. Sci. 51, 660-672 (1949)

26. Broyer, Y., Freychet, P., Rosslin, G.: Insulin and glucagonreceptor interactions in the genetically obese Zucker rat: studies of hormone binding and glucagon-stimulated cyclic AMP levels in isolated hepatocytes. Endocrinology 101, 236-249 (1977)

27. Kahn, C. R., Neville, D. M. Jr., Roth, J.: Insulin receptor interaction in the obese hyperglycemic mouse. J. Biol. Chem. 248, 244-250 (1973)

28. DeMeyts, P., Bianco, A.F., Roth, J.: Site-site interactions among insulin receptors. J. Biol. Chem. 251, 1877-1888 (1976)

29. DeMeyts, P., Roth, J., Neville, D. M. Jr., Gavin, J. R., Lesniak, M.A.: Insulin interactions with its receptors: experimental evidence for negative cooperativity. Biochem. Biophys. Res. Commun. 55, 154-161 (1973)

30. Hellman, B.: Calcium and pancreatic $\beta$-cell function. I. Stimulatory effects of pentobarbital on insulin relcasc. Biochim. Biophys. Acta 497, 766-774 (1977)

Received: June 14, 1977,

and in revised form: February 10, 1978

Prof. V. Marks

Division of Clinical Biochemistry

Department of Biochemistry

University of Surrey

Guilford, GU2 5XH, Surrey

England 